УДК 553.982

\title{
Efficient Use of Viscous and Heavy Oils of Russian Arctic Region
}

\author{
Natal'ya A. Krasnoyarova a,b, \\ Irina G. Yashchenko and Diana Yu. Chirkova ${ }^{\mathrm{a}, \mathrm{b}}$ * \\ ${ }^{a}$ Institute of Petroleum Chemistry $S B R A S$ \\ 4 Akademichesky, Tomsk, 634055, Russia \\ ${ }^{b}$ National Research Tomsk Polytechnic University \\ 30 Lenin, Tomsk, 634050, Russia
}

Received 19.04.2015, received in revised form 09.06.2015, accepted 17.07.2015

The paper presents the comparative analysis of physicochemical properties of oils in North American, Scandinavian, and Russian sectors of the Arctic. The analysis of oil reserve distribution in the arctic territory and aquatory shows that the Russian sector is much higher in oil reserves than North American and Scandinavian sectors. A study of physicochemical properties of viscous and heavy oils in the Russian part of the Arctic is presented in this paper.

Keyword: The Arctic, oil-gas resources, physic and chemical properties of oil, sulfur, waxes, resins, asphaltenes.

DOI: $10.17516 / 1998-2836-2015-8-3-318-326$.

(C) Siberian Federal University. All rights reserved

* Corresponding author E-mail address: sric@ipc.tsc.ru, natalex@ipc.tsc.ru 


\title{
Эффективное использование вязких
}

\section{и тяжелых нефтей Российской Арктики}

\author{
Н.А. Красноярова ${ }^{\mathbf{a}, \tilde{\sigma}}$, \\ И.Г. Ященко ${ }^{\mathrm{a}}$ Д.Ю. Чиркова ${ }^{\mathrm{a}, \boldsymbol{\sigma}}$ \\ ${ }^{a}$ Институт химии нефти СО РАН \\ Россия, 634055, Томск, пр. Академический, 4 \\ ${ }^{6}$ Национальный исследовательский \\ Томский политехнический университет \\ Россия, 634050, Томск, пр. Ленина, 30
}

Проведен сравнительный анализ физико-химических свойств нефтей Североамериканского, Скандинавского и Российского секторов Арктики. Анализ распределения запасов нефтей по арктической территории и акватории показал, что Российский сектор гораздо богаче нефтяными запасами, чем Североамериканский и Скандинавский. Проведен сравнительный анализ физико-химических свойств тяжельх и вязких нефтей России в Арктической зоне.

Ключевые слова: Арктика, нефтегазовые ресурсы, физико-химические свойства нефти, сера, парафины, смоль, асфальтеныл.

\section{Introduction}

In the $21^{\text {st }}$ century, it has become apparent that further economic development in Russia is impossible without reclamation of the Arctic region based on the new quality approach accounting for ecological priorities. Presently, such arctic countries as Russia, the USA, Canada, Norway, Denmark on behalf of Greenland and non-arctic countries display as well the great interest to reclamation of this region $^{1-4}$. The Arctic zone is divided into three large sectors, namely: North American, Scandinavian, and Russian. The oil-and-gas bearing zoning of the Arctic region is presented in Fig. 1. The Arctic mineral resource base contains the main group of minerals, i.e. hydrocarbons. Russia is one of the leading Arctic countries in the field of oil-and-gas reserves.

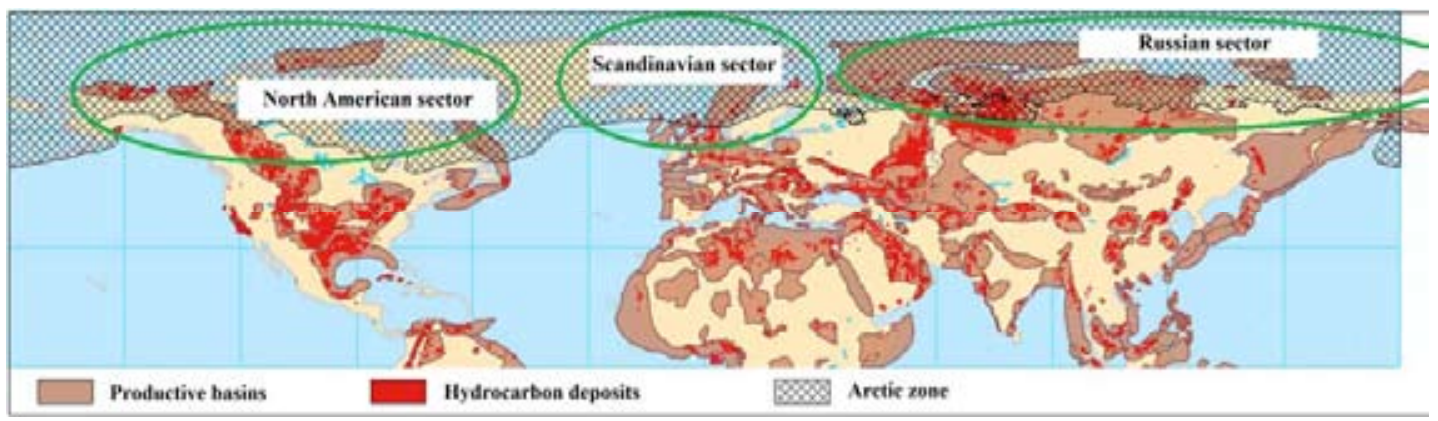

Fig. 1. Oil-and-gas bearing zoning of the Arctic region 


\section{Materials and methods}

The analysis of oil reserve distribution in the arctic territory and aquatory was carried out using the petroleum chemistry database created in the Institute of Petroleum Chemistry, SB RAS, Tomsk, Russia $^{5}$, which contains over 30000 oil types. The comparative analysis was conducted to study the physicochemical properties of oils of North American, Scandinavian, and Russian sectors. A special attention was paid to studying the properties of viscous and heavy oils of the Russian sector.

In order to provide the compositional analysis, the properties of oil from large, unique and hard to recover reserves of North-West Siberia were studied, namely: Arctic, Gydan, Zapolyarny, Novopotovskoe, and Russkoe fields. Both physicochemical properties and molecular composition of these oils were studied. Chromato-Mass-Spectrometry technique was used to identify normal and isoprenoid alkanes, the group of saturated cyclic hydrocarbons including steranes, hopanes, tri- and tetracyclic terpanes, alkyl-cyclohexanes and the group of aromatic hydrocarbons including n-alkyl benzenes, naphthalenes, phenanthrenes, biphenyls, fluorenes, fluoranthenes, pyrenes, and chrysenes. The in-depth compositional analysis of hydrocarbons was carried out with the Thermo Scientific DFS Chromato-Mass-Spectrometer System (Germany).

\section{Results and discussion}

Table 1 contains information about hydrocarbon deposit and resource distribution in the Arctic zone. In the Russian sector, the number of hydrocarbon deposits is 4 and 8 times higher than that of North American and Scandinavian sectors, respectively. The amount of hydrocarbon reserves in the Russian sector is also large and comes to almost $3 / 4$ of all arctic reserves.

Physicochemical properties of arctic oils are presented in Table 2 for the sectors under study. The statistical analysis shows that average values differ and reflect their changes in different sectors of the Arctic zone. Oils from North American sector are the heaviest as compared to those from Scandinavian and Russian sectors and contain more sulfur, asphaltenes and less paraffines and light fractions with boiling points $\leq 200{ }^{\circ} \mathrm{C}$. Oils from Russian sector refer to light oils, although are characterized by the high viscosity and the high content of such heavy metals as vanadium and nickel which corresponds to their profitable extraction. Scandinavian oils possess higher quality and are described by the average density, low viscosity, sulfur, asphaltenes, and metals, but are high in paraffines.

Table 1. Hydrocarbon deposit and resource distribution in Arctic zone

\begin{tabular}{|c|c|c|c|}
\hline Arctic zone & Productive basins & $\begin{array}{c}\text { Number of } \\
\text { hydrocarbon } \\
\text { deposits }\end{array}$ & $\begin{array}{l}\text { Hydrocarbon } \\
\text { reserves }(\%)\end{array}$ \\
\hline $\begin{array}{l}\text { North American } \\
\text { sector }\end{array}$ & $\begin{array}{l}\text { Alaska Arctic Slope, Beaufort, West-Canadian, } \\
\text { Labrador Region, Sverdrup Island }\end{array}$ & 165 & 18.50 \\
\hline Scandinavian sector & $\begin{array}{l}\text { West-Scotland, Norwegian Sea, Hatton, Middle } \\
\text { Europe, Shetland-Faeroes }\end{array}$ & 91 & 8.30 \\
\hline Russian sector & $\begin{array}{l}\text { Anadyr'-Navarinskii, Barents-Kara, East-Arctic, } \\
\text { Yeniseian-Anabar, West Siberian, Lena- } \\
\text { Vilyuysk, Lena-Tunguska, Penzhinsk, Pacific } \\
\text { Ocean region, Timan-Pechora, Ust'-Indigirsk, } \\
\text { South-Chukot }\end{array}$ & 731 & 73.20 \\
\hline
\end{tabular}


It should be noted that Scandinavian region is rich in heavy (over $0.88 \mathrm{~g} / \mathrm{cm}^{3}$ density) and viscous (over $35 \mathrm{~mm}^{2} / \mathrm{s}$ at $20^{\circ} \mathrm{C}$ ) oils that can be rather efficient for the production of arctic oils and paving bitumen ${ }^{2}$. Table 3 contains information about physicochemical properties of heavy and viscous oils in sectors under review.

The statistical analysis shows that heavy and viscous oils in the Russian sector are heavier and more viscous as compared to those from North American and Scandinavian sectors, and almost 1.5 2 times higher in sulfur and praffines. Heavy oils of North American sector are characterized by the higher asphaltene aggregation (3-10 times higher). Scandinavian oils possess higher quality, i.e. the lowest density and viscosity, low sulfur and asphaltenes.

The total area of the Russian sector is $30 \%$ larger than the territory of the whole Russia ${ }^{3}$. In compliance with the regulatory documents, it includes the part of the Sakha Yakutia Republic, Murmansk and Arkhangelsk regions, Novaya Zemlya Archipelago, Autonomous Areas of Taimyr, Yamalo-Nenets and Chukot, Republics of Karelia and Komi, and also territories and islands and adjacent continental waters, the territorial sea and continental shelf (Fig. 1).

The Russian Arctic region is of geopolitical, economical, defence, scientific, and socio-economic interests of the Russian Federation. The Russian sector is the largest petroleum reserve of the country

Table 2. Physicochemical properties of oils in Arctic zone

\begin{tabular}{lccc}
\hline \multicolumn{1}{c}{ Indicators } & $\begin{array}{c}\text { North American } \\
\text { sector }\end{array}$ & Scandinavian sector & Russian sector \\
\hline Density $\left(\mathrm{g} / \mathrm{cm}^{3}\right)$ & 0.8880 & 0.8471 & 0.8370 \\
Viscosity at $20^{\circ} \mathrm{C},\left(\mathrm{mm}^{2} / \mathrm{s}\right)$ & 26.27 & 7.89 & 421.16 \\
Viscosity at $50^{\circ} \mathrm{C},\left(\mathrm{mm}^{2} / \mathrm{s}\right)$ & 12.23 & 5.54 & 16.29 \\
Sulfur (wt. \%) & 0.99 & 0.36 & 0.59 \\
Paraffine (wt. \%) & 1.26 & 5.82 & 4.81 \\
Asphaltene (wt. \%) & 11.30 & 0.48 & 1.52 \\
Fraction boiling point $\leq 200{ }^{\circ} \mathrm{C},($ wt. \%) & 10 & 34 & 28.15 \\
Gas m $\mathrm{m}^{3} / \mathrm{t}$ & 219.67 & 187.45 & 142.27 \\
Vanadium (wt. \%) & 0.004 & 0.0002 & 0.004 \\
Nickel (wt. \%) & 0.001 & 0.0001 & 0.007 \\
\hline
\end{tabular}

Table 3. Physicochemical properties of heavy and viscous oils in Arctic zone

\begin{tabular}{lccc}
\hline \multicolumn{1}{c}{ Indicators } & North American sector & Scandinavian sector & Russian sector \\
\hline Density $(\mathrm{g} / \mathrm{cm} 3)$ & 0.9107 & 0.8955 & 0.9250 \\
Viscosity at $20^{\circ} \mathrm{C},(\mathrm{mm} 2 / \mathrm{s})$ & 37.68 & 22.67 & 621.40 \\
Viscosity at $50^{\circ} \mathrm{C},(\mathrm{mm} 2 / \mathrm{s})$ & 30.30 & 10.14 & 60.53 \\
Sulfur (wt. \%) & 1.16 & 0.48 & 1.60 \\
Paraffine (wt. \%) & 1.07 & 1.60 & 2.68 \\
Asphaltene (wt. \%) & 12.85 & 1.00 & 3.57 \\
\hline
\end{tabular}


after West and East Siberia regions that have been explored for the last time. This sector should be seriously prepared for reclamation during the next 10-15 years. The estimation of hydrocarbon potential of territories and aquatories of the Russian sector is given in Table 4.

According to Table 4, hydrocarbon deposits in the Russian Arctic zone are so significant that without the reclamation of this region the country will not be able to succesfully develop and exist. The estimation of hydrocarbon potential of territories and aquatories of the Russian sector of the Arctic requires considerable detailing and corrections since geologic-geophysical state of north territories and aquatories has not yet been well investigated. In specialists' opinion, the estimation of oil reserves of the Russian sector can be rather higher and comparable with productive basins of Near East ${ }^{2}$. Thus, the unique oil reserve Pobeda was discovered in Kara Sea by Rosneft Company. Research results on fluid, drilling sludge, and core samples obtained by OAO 'TomskNIPIneft' proved prognosis evaluations of the oil quality. The quality of this superlight oil surpasses that of Brent oil benchmark. It was found that the density of this oil is $0.808-0.814 \mathrm{~g} / \mathrm{cm}^{3}$. The weight content of sulfur in oil reserve Pobeda is only 0.02. Moreover, this oil type is characterized by the high output of light fractions (60-70\%) and the low resin content (1.5\%). At the same time, oils from northern and eastern territories and aquatories are hard to recover reserves due to difficult miningand-geological conditions such as permafrost.

As was mentioned above, the Russian sector is very high in hydrocarbon deposits, especially heavy and viscous oils. These are oils from the unique and large fields, namely: Russkoe, Novopotovskoe, Komsomol'skoe, Vyngapur, Zapadno-Messoyakhskoe, Tazovskoe in West Siberian basin; Naul'skoe, Yaregskoe, Medynskoe-More, Prirazlomnoe, Syurkharatinskoe, Toraveiskoe in Timan-Pechora basin; Olenekskoe in Lena-Tunguska basin, and others ${ }^{5,6}$. In connection with the interest to heavy and viscous oils (Canada, Venezuela) increased in the world, the problem of rationale for the optimum technologies and production models, transportation and processing of oil in Russia becomes very relevant. Heavy and viscous oils presented in Table 5 are medium -sour, -resinous, -asphaltene and low in sulfur diesel and associated gas. Also, a high content of vanadium and nickel is present.

In Russia, heavy oils are referred to hard to recover hydrocarbon reserves. They differ from traditional oil types not only by their high density but also composition. Moreover, heavy oils comprise naphthenic acids, sulphonated acids, simple and compound ethers which can be extracted by a special refining technology. The cost of these components in terms of marketable products obtained after the oil refinement can exceed the cost of oil products. The content of heavy metals in arctic oil satisfies the level of normal concentrations. Currently, oil companies neglect the extraction of associated

Table 4. Hydrocarbon deposits in territories and aquatories of the Russian Arctic zone

\begin{tabular}{lccccc}
\hline \multirow{2}{*}{$\begin{array}{c}\text { Territories and } \\
\text { aquatories }\end{array}$} & Oil (bln t) & $\begin{array}{c}\text { Associated gas } \\
\left(\text { bln m }^{3}\right)\end{array}$ & $\begin{array}{c}\text { Free gas } \\
\left(\operatorname{trn~m^{3}}\right)\end{array}$ & $\begin{array}{c}\text { Condensate } \\
(\mathrm{mn} \mathrm{t})\end{array}$ & $\begin{array}{c}\text { Total } \\
\text { hydrocarbon } \\
(\text { bln })\end{array}$ \\
\hline Territories & 51.2 & 2876.0 & 94.6 & 1378.0 & 150.1 \\
Aquatories & 19.4 & 2553.8 & 107.6 & 6325.2 & 135.7 \\
Total & 70.6 & 5429.8 & 202.2 & 7703.2 & 286.0 \\
\hline
\end{tabular}


components from heavy viscous oil. Besides, there are no efficient technologies for the extraction of associated components that could render a significant profit to oil companies.

Thus, for example, the quality of vanadium and nickel extracted from heavy viscous oil considerably exceeds the quality of analogs obtained from ore. Therefore, it is metal extracted from oil that the developed countries prefer to use in innovative technologies which provide the purity higher than in casthouse production. Canada and Japan produce vanadium completely from heavy viscous oils; the USA extracts over $80 \%$ of vanadium from oil as well. Since 2003, the demand for vanadium has been outstripped, and, obviously, will be continued despite the economy crisis.

In order to provide the compositional analysis, the properties of oil from large, unique and hard to recover reserves of North-West Siberia were studied, namely: Arctic, Gydan, Zapolyarny, Novopotovskoe, and Russkoe fields.

The comparative analysis of physicochemical properties shows that by its density this oil can be referred to light (Gydan field), medium (Zapolyarny and Arctic fields), heavy (Novopotovskoe field), and bitumen (Russkoe field) having over $0.895 \mathrm{~g} / \mathrm{cm}^{3}$ density. By contrast to other types, the oil from Russkoe field is high viscous. The properties and hydrocarbon content of oils from North-West Siberia is given in Table 6.

Chromato-Mass-Spectrometry shows that alkanes prevail over other hydrocarbon groups in all oils. However, unlike all other oils, bitumen oil from Russkoe field has a higher content of saturated cyclic hydrocarbons, while heavy oil from Novopotovskoe field is high in aromatic hydrocarbons (Fig. 2). Infrared spectroscopy shows that the aromaticity coefficient $C_{1}$ reaches its maximum in heavy oil of Novopotovskoe field ${ }^{10}$.

The use of these data for advanced oil processing, efficient and economical use of hydrocarbon deposits will allow not only to improve such processes as thermal and catalytic cracking, but also change the viewpoint concerning the existing oil refining technologies.

Table 5. Physicochemical properties of heavy viscous oils in Arctic zone of Russia

\begin{tabular}{|c|c|}
\hline Indicators & Heavy viscous oils \\
\hline Density $\left(\mathrm{g} / \mathrm{cm}^{3}\right)$ & 0.9250 \\
\hline Viscosity at $20^{\circ} \mathrm{C},\left(\mathrm{mm}^{2} / \mathrm{s}\right)$ & 621.40 \\
\hline Viscosity at $50^{\circ} \mathrm{C},\left(\mathrm{mm}^{2} / \mathrm{s}\right)$ & 60.53 \\
\hline Sulfur (wt. \%) & 1.60 \\
\hline Paraffine (wt. \%) & 2.68 \\
\hline Resins (wt. \%) & 9.99 \\
\hline Asphaltene (wt. \%) & 3.57 \\
\hline Fraction boiling point $\leq 200^{\circ} \mathrm{C},($ wt. $\%$ ) & 11.86 \\
\hline Fraction boiling point $\leq 300^{\circ} \mathrm{C},($ wt. $\%)$ & 24.21 \\
\hline Fraction boiling point $\leq 350^{\circ} \mathrm{C},(\mathrm{wt} . \%)$ & 33.13 \\
\hline Gas $\mathrm{m}^{3} / \mathrm{t}$ & 43.42 \\
\hline Vanadium (wt. \%) & 0.0067 \\
\hline Nickel (wt. \%) & 0.0141 \\
\hline
\end{tabular}


Table 6. Properties and hydrocarbon content of oils from North-West Siberia

\begin{tabular}{llllll}
\hline \multicolumn{1}{c}{ Area } & Zapolyarny & Arctic & Gydan & Novopotovskoe & Russkoe \\
\hline Density $\left(\mathrm{g} / \mathrm{cm}^{3}\right)$ & 0,8640 & 0,8510 & 0,8300 & 0,9150 & 0,9390 \\
Viscosity $(\mathrm{MPa} \cdot \mathrm{s})$ & 11,10 & 9,50 & 2,90 & 5,80 & 515,40 \\
Alkanes (\%) & 77,00 & 75,60 & 82,70 & 50,90 & 39,60 \\
Saturated cyclic hydrocarbons (\%) & 9,60 & 8,30 & 8,30 & 21,00 & 38,20 \\
Aromatic hydrocarbons (\%) & 13,40 & 16,10 & 9,00 & 28,10 & 19,90 \\
\hline
\end{tabular}
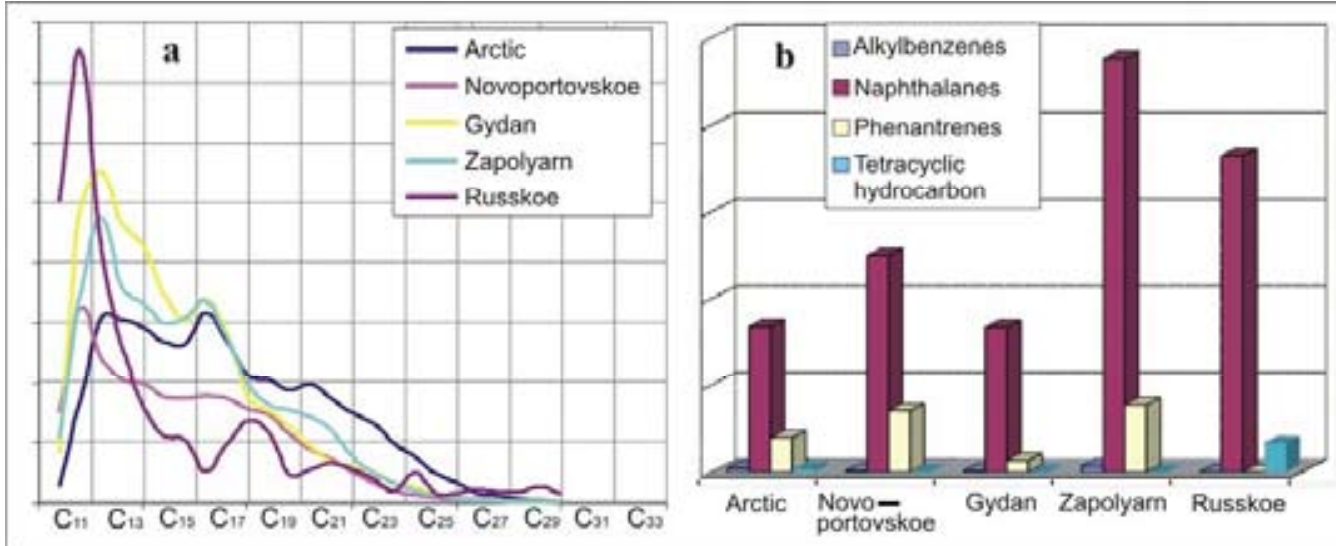

Fig. 2. Oil composition from North-West Siberia by: (a) n-alkanes; (b) aromatic hydrocarbons

Table 7. Physicochemical properties of heavy viscous oils of Novopotovskoe and Russkoe fields

\begin{tabular}{lcc}
\hline \multicolumn{1}{c}{ Indicators } & Novopotovskoe field & Russkoe field \\
\hline Density $\left(\mathrm{g} / \mathrm{cm}^{3}\right)$ & 0.9147 & 0.9382 \\
Viscosity at $20^{\circ} \mathrm{C},\left(\mathrm{mm}^{2} / \mathrm{s}\right)$ & 38.99 & 556.88 \\
Sulfur (wt. \%) & 0.18 & 0.32 \\
Paraffine (wt. \%) & 1.10 & 1.18 \\
Resins (wt. \%) & 4.75 & 11.05 \\
Asphaltene (wt. \%) & 0.33 & 0.72 \\
Fraction boiling point $\leq 200^{\circ} \mathrm{C}$, (wt. \%) & 0.90 & 0.89 \\
Fraction boiling point $\leq 300^{\circ} \mathrm{C}$, (wt. \%) & 40.04 & 16.87 \\
Fraction boiling point $\leq 350^{\circ} \mathrm{C}$, (wt. \%) & 46.52 & 28.19 \\
\hline
\end{tabular}

Novopotovskoe and Russkoe fields possess large reserves of heavy and viscous oils, the average physicochemical properties of which are given in Table 7. Physicochemical properties of these oils slightly differ. On the average, oils are low in sulfur, resin, asphaltenes, and diesel fractions. Oils from Russkoe field possess higher viscosity and are twice as high resins and asphaltenes as oils from 
Novopotovskoe field at a lower amount of end point fractions in comparison with Novopotovskoe field.

Oils from Russkoe field can become the main natural source of deficient naphthene oil production. According to Table 7, oils from Russkoe field is the unique raw material since it refers to heavy oils low in paraffines and sulfur with the minimum content of light fractions with boiling points $\leq 200{ }^{\circ} \mathrm{C}(>1.0$ wt. \% boils off). Today, naphthene oils having a high viscosity index produced from low-paraffine oils of Russkoe field is rather difficult and implies the application of up-to-date hydro-catalytic technologies. However, a wide range of their applications (the production of industrial, dielectric, hydraulic, transmission, refrigerator and other oils) provides the efficient use of hard to recover reserves of the Arctic. For example, in the USA and Canada, $20 \%$ of base oils are based just on heavy hydrocarbon feedstock refining. In the Russian part of the Arctic, it is important and expedient to bring industry nearer to the heavy oil output that will allow the development of the petroleum chemistry production and efficient and high-performance technologies. The Arctic has opportunities to become the largest manufacturer of diverse petroleum products and perform its sustainable delivery to the home and, in the future, international market as well.

\section{Conclusions}

It is shown that the Russian sector of the Arctic zone is much richer in oil and gas than other sectors. Oils of the Russian sector belong to the light oil type, but are characterized by high viscosity and high content of heavy metals, such as vanadium and nickel the content of which corresponds to their profitable extraction. There are no currently efficient extraction technologies for such associated components as naphthenic acids, sulphonated acids, simple and compound ethers, heavy metals that could render a significant profit to oil companies. The properties and composition of heavy viscous oils from West Siberia is the main recommendation for their refining using the advanced technologies and production models for a wide range of petroleum products.

\section{Acknowledgements}

The authors wish to acknowledge the assistance and support of Core Facilities Centre of the Tomsk Research Centre SB RAS for carrying out this research. The assistance of A/Professor P. Kadychagov, our colleague, in carrying out the analysis on the Thermo Scientific DFS ChromatoMass-Spectrometer is gratefully acknowledged. Thanks also go to M. Vorob'eva, the translator from Tomsk State University of Architecture and Building for translation of this paper.

\section{References}

1. Askhabov A.M., Burtsev I.N., Kuznetsov S.K., Timonina N.N. Arkticheskii vektor geologicheskikh issledovanii: neftegazovye i mineral'no-syr'evye resursy [Geological explorations in the Arctic: oil-and-gas and mineral raw materials] // Vestnik Inst Geol Komi SC UB RAS. 2014. № 9. P. 3-10.

2. Kontorovich A.E. Energoresursy Rossiiskogo sektora Arktiki, glavnye napravleniya i metody ikh osvoeniya [Energy resources of the Russian sector of Arctic, main trends and methods of reclamation]. In: Nauchno-tekhnicheskie problemy osvoeniya Arktiki. Nauchnaya sessiya Obshchego sobraniya chlenov RAN 16 dekabrya 2014 g. Moscow: Nauka, 2014.

$$
-325-
$$


3. Bortnikov N.S. Strategicheskie mineral'nye resursy rossiiskoi Arktiki i problemy ikh osvoeniya [Strategic mineral resources of the Russian sector of the Arctic and reclamation problems]. In: Nauchno-tekhnicheskie problemy osvoeniya Arktiki. Nauchnaya sessiya Obshchego sobraniya chlenov RAN 16 dekabrya 2014 g. Moscow: Nauka, 2014.

4. Kaminskii V.D., Suprunenko O.I., Smirnov A.N. Mineral'no-syr'evye resursy arkticheskoi kontinental'noi okrainy Rossii i perspektivy ikh osvoeniya [Mineral raw materials of Arctic continental zone of Russia and prospective reclamation] // Arktika. Ekologiya i ekonomika. 2014. № 3. P. 52-61.

5. Yashchenko I.G., Polishchuk Yu.M. Trudnoizvlekaemye nefti: fiziko-khimicheskie svoistva i zakonomernosti razmeshcheniya [Hard to extract oils: physicochemical properties and deposit laws]. Tomsk: V-Spektr; 2014.

6. Polishchuk Yu.M., Yashchenko I.G. Heavy oils: Regularities of spatial distribution// Neftyanoe khozyaistvo - Oil Industry. 2006. № 2. P. 110-113.

7. Yashchenko I.G. Toksoopasnye tyazhelye nefti Rossii: regional'nye i kachestvennye osobennosti [Toxic heavy oils of Russia: regional and qualitative properties] // Ekologicheskii vestnik Rossii. 2013. № 6. P. 26-33.

8. Yashchenko I.G. Tyazhelye vanadievonosnye nefti Rossii [Heavy vanadium oils of Russia] // Bulletin TPU. 2012. № 1. P. 105-111.

9. Lur'e MA, Shmidt FK. Sulfur and metal contents - genetic aspects of crude oils // Chem Tech Fuels Oils. 2009. № 4. P. 242-245.

10. Chirkova O.V., Krasnoyarova N.A., Serebrennikova O.V. Issledovanie svoistv, sostava i raspredeleniya uglevodorodnykh soedinenii v neftyakh severa Zapadnoi Sibiri [A study of properties, composition, and distribution of hydrocarbon compounds in oils of North-West Siberia]. In: Proc Sci Conf 'Theoretical and Practical Problems of Science and Education'. Tambov: Yukom; 2015. 